\title{
PENGARUH PEMBELAJARAN KEWIRAUSAHAAN, PRAKTIK KERJA INDUSTRI, DAN PENGETAHUAN KEWIRAUSAHAAN TERHADAP KESIAPAN BERWIRAUSAHA
}

\author{
Lukman Anggriawan \\ e-mail: lukmanandriawan@gmail.com \\ Rusno \\ e-mail: rusno@unikama.ac.id \\ Riril Mardiana Firdaus \\ e-mail: ririlmardiana@unikama.ac.id
}

(Program Studi Pendidikan Ekonomi, Fakultas Ekonomika dan Bisnis, Universitas Kanjuruhan, Malang)

\begin{abstract}
This research aimed to show the influence of entrepreneurship learning, field work industry and entrepreneurship knowledge towards the readiness of doing an entreprenenur. This research use quantitative approach with expo-facto method. The number of population was 126 students at SMK Budi Mulia Pakisaji. The number of sampling was 65 students which is determined by using proportional random sampling. The technique of data collection was using questionnaire. Based on analysis result, it could be concluded; there was an influence of entrepreneurship learning, field work industry and entrepreneurship knowledge towards the readiness of doing an entreprenenur, simultaneously, there was an influence of entrepreneurship learning, field work industry and entrepreneurship knowledge towards the readiness of doing an entreprenenur and $R^{2}$ value amount $0,779 \%$ it means that the influence of doing entrepreneurship learning, field work industry and entrepreneurship knowledge amount $77 \%$ towards the readiness of doing an entrepreneur.
\end{abstract}

Keywords : Entrepreneurship learning, Field work industry, Entrepreneurship knowledge, Entrepreneur readiness

\begin{abstract}
Abstrak: Tujuan penelitian untuk mengungkapkan pengaruh pembelajaran kewirausahaan, praktik kerja industri, dan pengetahuan kewirausahaan terhadap kesiapan berwirausaha. Penelitian menggunakan pendekatan kuantitatif dengan jenis penelitian ekspo-facto. Populasi berjumlah 126 siswa di SMK Budi Mulia Pakisaji. Sampel sebanyak 65 siswa ditentukan menggunakan proportional random sampling. Teknik pengumpulan data menggunakan angket. Berdasarkan hasil analisis dapat ditarik beberapa kesimpulan diantaranya : ada pengaruh pembelajaran kewirausahaan terhadap kesiapan berwirausaha, ada pengaruh praktik kerja industri terhadap kesiapan berwirausaha, ada pengaruh pengetahuan kewirausahaan terhadap kesiapan berwirausaha, ada pengaruh secara simultan pembelajaran kewirausahaan, praktik kerja industri, dan pengetahuan kewirausahaan terhadap kesiapan berwirausaha dan nilai R2 sebesar 0,779 yang berarti pembelajaran kewirausahaan, praktik kerja industri dan pengetahuan kewirausahaan berpengaruh sebesar $77 \%$ terhadap kesiapan berwirausaha.
\end{abstract}

Kata kunci : Pembelajaran Kewirausahaan, Praktik Kerja Industri, Pengetahuan Kewirausahaa, Kesiapan Berwirausaha 


\section{PENDAHULUAN}

Pendidikan sebagai pengembangan kemampuan dan untuk membentuk watak yang sesuai dengan Undang-Undang 1945 serta peradaban bangsa yang bermartabat dalam rangka mencerdaskan kemajuan bangsa. Salah satu misi dari pendidikan nasional adalah memberdayakan peran masyarakat dalam penyelenggaraan pendidikan berdasarkan prinsip otonomi dalam konteks Negara Kesatuan Republik Indonesia, serta untuk meningkatkan keprofesionalan dan akuntabilitas lembaga pendidikan sebagai pusat pembudayaan ilmu pengetahuan, keterampilan, pengalaman, sikap, dan nilai berdasarkan standar nasional dan global. Indonesia adalah negara yang sangat banyak jumlah penduduknya. Jumlah penduduk Indonesia yang dibilang sangat banyak ini, kemungkinan besar akan semakin banyak menimbulkan permasalahan. Diantara permasalahan yang timbul salah satunya adalah sempitnya lapangan pekerjaan dan meningkatnya jumlah penduduk yang dapat mengakibatkan jumlah pengangguran semakin banyak dan meningkat.

Kesiapan berwirausaha merupakan suatu kemauan dan keinginan seseorang untuk berwirausaha. Kemauan dan keinginan seseorang tersebut bergantung pada tingkat kematangan, pengalaman masa lalu, keadaan mental dan emosi seseorang. Untuk memasuki dunia kerja seseorang harus memiliki bekal. Di antara bekal tersebut antara lain: kesiapan mental, kesiapan pengetahuan dan kesiapan sumber daya. Hal penting untuk mengoptimalkan potensi dan menimbulkan kesiapan berwirausaha adalah dengan cara mengetahui pengetahuan kewirausahaan dari siswa itu sendiri. Menurut Slameto (2010:113) “Kesiapan (readiness) adalah keseluruhan kondisi seseorang yang membuatnya siap untuk memberi respon atau jawaban di dalam cara tertentu terhadap suatu situasi. Penyesuaian kondisi suatu saat akan berpengaruh pada kecenderungan untuk memberi respon".

Faktor yang dapat mempengaruhi kesiapan berwirausaha adalah pembelajaran kewirausahaan. Pembelajaran kewirausahaan merupakan salah satu ciri muatan yang diajarkan pada kurikulum tingkat satuan pendidikan SMK. Dalama hal ini diharapkan untuk menumbuhkan kesiapan siswa dalam berwirausaha, sehingga siswa mampu menciptakan lapangan pekerjaan sendiri sesuai dengan masing-masing keterampilan dan keahlian yang dimilikinya. Pembelajaran adalah suatu proses interaksi antara peserta didik dan pendidik, dan antara peserta dan sumber belajar lainnya pada suatu lingkungan belajar yang berlangsung secara edukatif

Faktor lain yang dapat mempengaruhi kesiapan berwirausaha adalah praktik kerja industri. Praktik kerja industri merupakan kegiatan pendidikan dan latihan kerja dengan mengembangkan kemampuan, keahlian, dan profesi di tempat kerja sesuai dengan bidang studi atau jurusan masingmasing siswa. SMK Budi Mulia Pakisaji mendidik siswanya untuk menjadi manusia yang mampu mengaplikasikan ilmunya di dunia industri. Siswa akan dibekali dengan keterampilan dan ilmu-ilmu yang bermanfaat dalam kewirausahaan sehingga mereka bisa berwirausaha jika mereka tidak ingin melanjutkan ke perguruan tinggi.

Selain faktor-faktor diatas ada juga faktor yang dapat mempengaruhi kesiapan berwirausaha adalah pengetahuan kewirausahaan. Pengetahuan berwirausaha akan menjadikan seseorang untuk lebih giat mencari dan memanfaatkan peluang usaha dengan mengoptimalkan potensi yang dimiliki. Pengetahuan dan keterampilan siswa yang diperoleh selama di bangku sekolah merupakan modal dasar yang dapat digunakan untuk berwirausaha. Pengetahuan, keterampilan, pengalaman kerja industri serta kemampuan kerja yang dimiliki oleh siswa dapat mendorong tumbuhnya kesiapan untuk berwirausaha. Namun dalam hal pengetahuan ini siswa tidak difokuskan pada pengetahuan di sekolah saja melainkan diluar sekolah yakni lingkungan masyarakat sekitarnya yang telah banyak memberikan pengetahuan tentang kewirausahaan.

Berdasarkan penjelasan diatas, bisa ditarik kesimpulan bahwa antara pembelajaran kewirausahaan, praktik kerja industri, dan pengetahuan kewirausahaan saling berkaitan dalam kesiapan berwirausaha. Dalam penelitian kali ini, peneliti memilih lokasi di SMK Budi Mulia Pakisaji alternatif pertama kerena jarak antara tempat tinggal dan sekolah dekat, kedua sekolah tersebut 
merupakan tempat magang peneliti sehingga memperudah penelitian, ketiga peneliti ingin mengetahui kesiapan berwirausaha di SMK Budi Mulia Pakisaji yang notabennya adalah sekolah menengah kejuruhan yang berada di Kabupaten Malang.

Tujuan penelitian yang ingin dicapai dalam penelitian ini adalah (1) Untuk menganalisis pengaruh pembelajaran kewirausahaan, praktik kerja industri, dan pengetahuan kewirausahaan terhadap kesiapan berwirausaha. (2) Untuk menganalisis pengaruh pembelajaran kewirausahaan terhadap kesiapan berwirausaha. (3) Untuk menganalisis pengaruh praktik kerja industri terhadap kesiapan berwirausaha. (4) Untuk menganalisis pengaruh pengetahuan kewirausahaan terhadap kesiapan berwirausaha.

\section{TINJAUAN PUSTAKA}

\section{Kesiapan Berwirausaha}

Perkembangan ilmu dan teknologi serta tuntutan dunia kerja yang sangat cepat, mengakibatkan perkembangan pendidikan yang semakin cepat serta tuntutan terhadap mutu pendidikan yang semakin tinggi. Semakin ketatnya persaingan untuk mendapatkan pekerjaan di dunia usaha/industri menuntut Sekolah Menengah Kejuruan (SMK) meningkatkan daya saing lulusannya. Siswa SMK memang dipersiapkan untuk segera dapat memasuki lapangan kerja setelah tamat dari pendidikannya. Untuk dapat segera memasuki dunia kerja dibutuhkan adanya kesiapan kerja, yang meliputi kesiapan diri baik secara fisik maupun psikis yang merupakan langkah awal untuk meniti nantinya. Menurut Slameto (2010:113) "Kesiapan (readiness) adalah keseluruhan kondisi seseorang yang membuatnya siap untuk memberi respon atau jawaban di dalam cara tertentu terhadap suatu situasi. Penyesuaian kondisi suatu saat akan berpengaruh pada kecenderungan untuk memberi respon".

Kewirausahaan (entrepreneurship) adalah suatu disiplin ilmu yang mempelajari tentang nilai, kemampuan (ability), dan perilaku seseorang dalam menghadapi tantangan hidup dan cara memperoleh peluang dengan berbagai resiko yang mungkin dihadapinya. Menurut Rusdiana (2013:45) dilihat dari segi etimologi, kewirausahaan berasal dari kata wira dan usaha. Wira berarti pejuang, pahlawan, manusia unggul, teladan, berbudi luhur, gagah berani, dan berwatak agung. Adapun usaha berarti perbuatan amal, bekerja, berbuat sesuatu. Dengan demikian, wirausaha adalah pejuang atau pahlawan yang berbuat sesuatu.

Dilihat dari beberapa pendapat di atas sudah sepatutnya jika lulusan SMK yang telah mempelajari disiplin ilmu tentang kewirausahaan dan sudah mampu menghadapi tantangan hidup untuk menjadi seorang wirausaha yang seharusnya bisa membantu seseorang dalam bekerja terlebih menciptakan lapangan pekerjaan, tidak menutup kemungkinan lulusan SMK sudah dapat berjuang untuk berbuat sesuatu. Maka dari itu dapat disimpulkan bahwa berwirausaha adalah menciptakan atau membuat sesuatu untuk membantu seseorang dapat mendapatkan pekerjaan yang layak dalam kehidupannya.

\section{Pembelajaran Kewirausahaan}

Pembelajaran kewirausahaan adalah proses pemberian dan penerimaan atau penambahan pengetahuan mengenai kewirausahaan yang dilakukan dalam lingkup usaha kecil yaitu dalam proses pemberian mata pelajaran disekolah ataupun kegiatan non formal. Wirausaha yang sukses pada umumnya adalah mereka yang memiliki kompetensi dalam ilmu pengetahuan, keterampilan 
dan kualitas individu yang meliputi sikap, motivasi, nilai serta tingkah laku yang diperlukan untuk melaksanakan pekerjaan atau kegiatan.

Menurut Rusdiana (2013: 52-53) Pendekatan pembelajaran kewirausahaan diarahkan pada konsep kewirausahaan eksistensial. Konsep ini memfokuskan pemahaman kewirausahaan yang berorientasi pada aktualisasi jati diri dan potensi diri sebagai pembelajar kewirausahaan. Kata "eksistensial" memiliki tiga arti, yaityu: (a) keberadaan manusia atau cara khusus manusia dalam menjalani hidupnya; (b) makna hidup; (c) perjuangan manusia untuk menemukan makna yang kongkret di dalam hidupnya. Dengan kata lain, keinginan seseorang untuk mencari makna hidup. Kewirausahaan eksistensial sebagai jalur aktualisasi potensi-potensi diri (bakat, sikap, pengetahuan, keterampilan) untuk menciptakan "dunia esok" lebih baik dari "dunia kini" dengan menghasilkan produk atau jasa yang berfungsi meningkatkan kualitas hidup sesama manusia dan menyajikannya pada tingkat harga dan tempat yang terjangkau oleh pemakai (konsumen) yang membutuhkan serta mengendalikan konsekuensi penerimaan yang wajar bagi dirinya dan para stakeholders dan mengendalikan dampak kearah positif bagi komunitas lokal, komunitas bisnis, dan lingkungan global dengan menjadikan entitas bisnisnya sebagai simpul komunitas stakeholders.

\section{Praktik Kerja Industri}

Menurut Naswati (2015) menyatakan bahwa pengalaman yang diperoleh pada saat melakukan praktik kerja industri secara tidak langsung akan mempercepat transisi siswa dari sekolah ke dunia industri, selain mempelajari cara mendapatkan pekerjaan juga belajar bagaimana memiliki pekerjaan yang relevan dengan bakat dan minat. Karena bakat dan minat akan mendorong individu untuk memusatkan perhatian dan meningkatkan aktivitas mental dan kegiatan yang sesuai dengan minatnya. Pengalaman dalam hal ini yaitu pengalaman yang didapat setelah melaksanakan praktik kerja industri, pengalaman kerja inilah yang akan menentukan minat siswa untuk berwirausaha karena didalam industri siswa diajarkan untuk bekerja dengan kemampuan sendiri sehingga mereka akan mandiri. Berdasarkan uraian di atas dapat disimpulkan bahwa praktik kerja industri mempunyai manfaat yang besar terutama untuk siswa, yaitu dapat memberikan kesempatan untuk berlatih keterampilan dalam kondisi yang sesungguhnya, memberikan pengalaman praktis dan siswa dapat menggunakan seluruh kemampuannya sebagai jembatan bagi dirinya untuk memasuki dunia kerja.

\section{Pengetahuan Kewirausahaan}

Menurut Nitisusastro (2010:87) mengatakan bahwa seyogyanya sebelum memasuki dunia usaha seseorang perlu membekali diri dengan pengetahuan tentang bidang usaha yang akan digeluti. Mengetahui dan memahami tentang seluk beluk suatu bidang usaha sama artinya dengan menguasai kompetensi. Seorang wirausaha tidak akan berhasil apabila tidak memiliki pengetahuan, kemampuan, dan keterampilan sesuai dengan ungkapan Michael Harris dalam Suryana (2014:81). Wirausaha yang sukses pada umumnya adalah mereka yang memiliki kompetensi, yaitu yang memiliki ilmu pengetahuan, keterampilan, dan kualitas individual yang meliputi sikap, motivasi, nilai-nilai pribadi, serta tingkah laku yang diperlukan untuk melaksanakan pekerjaan/kegiatan.

Jadi pengetahuan adalah segenap gambaran tentang suatu obyek tertentu atau subyek yang ada disekelilingnya yang terbentuk dan tertanam secara sadar pada pikiran seseorang melalui pengalaman dan pendidikan sehingga akan memperkaya khasanah mental yang kemudian secara langsung maupun tidak langsung turut memperkaya kehidupan manusia 


\section{METODE}

Jenis penelitian yang digunakan adalah ekspo-facto. Penelitian telah dilaksanakan di SMK Budi Mulia Pakisaji. Populasi berjumlah 126 siswa dan sampel penelitian 65 siswa yang ditentukan dengan teknik proportional random sampling. Variabel dalam penelitian ini terdiri dari tiga variabel bebas (independent variable). Variabel tersebut diberi simbol X1, X2 dan X3, yaitu pembelajaran kewirausahaan, praktik kerja industri, dan pengetahuan kewirausahaan. Variabel terikat (dependent variable) diberi simbol Y yaitu kesiapan berwirausaha. Data variabel Y, X1, X2, dan X3 dikumpulkan menggunakan instrumen kuesioner (angket).

\section{HASIL DAN PEMBAHASAN}

Berdasarkan permasalahan tersebut, analisis kontribusi pembelajaran kewirausahaan, praktik kerja industri, dan pengetahuan kewirausahaan terhadap kesiapan berwirausaha. Berikut ini adalah hasil analisis data dan pengujian hipotesis yang telah dilakukan.

Berdasarkan hasil perhitungan dapat diketahui nilai: $\mathrm{a}=13,777, \mathrm{~b} 1=, 429 \mathrm{~b} 2=252, \mathrm{~b} 3=, 462$ maka dapat disusun persamaan regresi linear berganda sebagai berikut:

$$
\begin{aligned}
& Y=a+b 1 X 1+b 2 X 2+b 3 X 3+e \\
& Y=13,777+0,429(X 1)+0,252(X 2)+0,462(X 3)
\end{aligned}
$$

Konstanta sebesar 13,777 memiliki arti jika variabel X1, X2 dan X3 atau jika variabel X1, X2 dan X3 bernilai nol, maka nilai variabel dependen (Y) akan sebesar 13,777. Nilai koefisien regresi variabel X1 (pembelajaran kewirausahaan) sebesar 0,429, artinya jika variabel X1 ditingkatkan 1 akan menyebabkan peningkatan hasil belajar sebesar 0,429. Nilai koefisien regresi variabel X2 (praktik kerja industri) sebesar 0,252, artinya jika variabel X2 ditingkatkan 1 akan menyebabkan peningkatan hasil belajar sebesar 0,252. Nilai koefisien regresi variabel X3 (pengetahuan kewirausahaan) sebesar 0,462, artinya jika variabel X3 ditingkatkan 1 akan menyebabkan penurunan hasil belajar sebesar 0,462 .

Jika dilihat dari nilai hasil analisis uji $\mathrm{F}$ didapat statistik nilai $\mathrm{F}$ sebesar 71,561 dengan tingkat signifikan 0,000 karena tingkat signifikan lebih kecil dari 0,05, maka hasil penelitian ini menolak hipotesis penelitan Ho1 dan menerima hipotesis penelitian Ha1 yaitu ada pengaruh yang signifikan secara simultan antara pembelajaran kewirausahaan, praktik kerja industri, dan pengetahuan kewirausahaan terhadap kesiapan berwirausaha.

Nilai Koefisien Determinasi (R Square) menunjukkan besarnya pengaruh seluruh variabel bebas yaitu pembelajaran kewirausahaan (X1), praktik kerja industri (X2), dan pengetahuan kewirausahaan (X3) terhadap kesiapan berwirausaha (Y), jadi (R Square) 0,779 memiliki makna pembelajaran kewirausahaan, praktik kerja industri, dan pengetahuan kewirausahaan mampu memberikan kontribusi sebesar $77 \%$ terhadap kesiapan berwirausaha $(\mathrm{Y})$ dengan demikian sisanya $32 \%$ dipengaruhi oleh variabel lain yang tidak termasuk dalam penelitian ini.

Untuk mengetahui pengujian hipotesis pertama, maka menggunakan uji $\mathrm{F}$ dan untuk menguji hipotesis ke dua, tiga, dan empat menggunakan uji t. 
Pengaruh pembelajaran kewirausahaan, praktik kerja industri, dan pengetahuan kewirausahaan terhadap kesiapan berwirausaha

Hasil statistik menunjukkan bahwa ada pengaruh yang signifikan pembelajaran kewirausahaan, praktik kerja industri, danpengetahuan kewirausahaan terhadap kesiapan berwirausaha. Hal ini dibuktikan dari hasil analisis uji $\mathrm{F}$ didapat statistik nilai $\mathrm{F}$ sebesar 71,561 dengan tingkat signifikan 0,000 karena tingkat signifikan lebih kecil dari 0,05, maka hasil penelitian ini menolak hipotesis penelitian Ho1 dan menerima hipotesis penelitian $\mathrm{H} 1$ yaitu: ada pengaruh yang signifikan secara simultan antara pembelajaran kewirausahaan, praktik kerja industri, dan pengetahuan kewirausahaan terhadap kesiapan berwirausaha.

\section{Pengaruh pembelajaran kewirausahaan terhadap kesiapan berwirausaha}

Hasil analisis statistik menunjukkan bahwa ada pengaruh yang signifikan antara pembelajaran kewirausahaan terhadap kesiapan berwirausaha. Hal ini dibuktikan dari hasil analisis uji t untuk variabel X1 (pembelajaran kewirausahaan) sebesar 4,141 dengan tingkat signifikan sebesar 0,000. Karena tingkat signifikannya lebih kecil dari 0,05, maka variabel X1 (pembelajaran kewirausahaan berpengaruh terhadap variabel Y (kesiapan berwirausaha). Sehingga $\mathrm{H} 2$ diterima dan Ho2 ditolak.

\section{Pengaruh praktik kerja industri terhadap kesiapan berwirausaha}

Hasil analisis statistik menunjukkan bahwa ada pengaruh yang signifikan antara praktik kerja industri terhadap kesiapan berwirausaha. Hal ini dibuktikan dari hasil analisis uji $t$ untuk variabel X2 (praktik kerja industri) sebesar 2,348 dengan tingkat signifikan sebesar 0,022. Karena tingkat signifikannya lebih kecil dari 0,05, maka variabel X2 (praktik kerja industri) berpengaruh terhadap variabel Y (minat melanjutkan ke perguruan tinggi). Sehingga H3 diterima dan Ho3 ditolak.

Pengaruh tingkat kemampuan akademik terhadap minat melanjutkan ke perguruan tinggi

Hasil analisis statistik menunjukkan bahwa ada pengaruh yang signifikan antara pengetahuan kewirausahaan terhadap kesiapan berwirausaha. Hal ini dibuktikan dari hasil analisis uji t untuk variabel X3 (pengetahuan kewirausahaan) sebesar 5,226 dengan tingkat signifikan sebesar 0,000. Karena tingkat signifikannya lebih kecil dari 0,05, maka variabel X3 (pengetahuan kewirausahaan) berpengaruh terhadap variabel Y (minat melanjutkan ke perguruan tinggi). Sehingga H4 diterima dan Ho4 ditolak.

\section{KESIMPULAN}

Berdasarkan hasil analisis yang telah dikemukakan pada bab sebelumnya, maka dapat ditarik beberapa kesimpulkan bahwa ada pengaruh positif dan signifikan pembelajaran kewirausahaan, praktik kerja industri, dan pengetahuan kewirausahaan terhadap kesiapan berwirausaha. Berdasarkan hasil penelitian ini, maka saran yang diajukan adalah (1) Bagi Sekolah, Sebagai usaha bagi sekolah untuk dapat meningkatkan tingkat kesiapan berwirausaha agar sekolah mampu mencetak sumber daya manusia yang berkualitas, (2) Bagi Guru, Hendaknya pada saat praktik kerja industri guru menempatkan siswa pada perusahaan yang sesuai dengan karakter siswa, perusahaan yang menarik, dan sesuai dengan kemampuan yang dimiliki siswa. Diharapkan dapat memanfaatkan pembelajaran kewirausahaan, praktik kerja industri, dan pengetahuan kewirausahaan guna memotivasi siswa dalam berwirausaha. Karena pembelajaran kewirausahaan, praktik kerja industri, dan pengetahuan kewirausahaan mempunyai pengaruh yang besar dalam perkembangan 
kesiapan siswa. (3) Bagi Siswa, Agar siswa mengetahui seberapa besar pengaruh pembelajaran kewirausahaan, praktik kerja industri, dan pengetahuan kewirausahaan terhadap kesiapan berwirausaha sehingga dapat digunakan ojeh siswa sebagai dasar dalam pengambilan keputusan. (4) Bagi Peneliti Selanjutnya, penelitian ini masih dapat dikembangkan lagi melalui variabel yang belum diteliti oleh penelitian ini. Variabel yang dapat digunakan untuk mempengaruhi kesiapan berwirausahai antara lain: dukungan keluarga, lingkungan, kepribadian, kecerdasaan, norma subyektif, sikap berperilaku dan karakteristik kewirausahaan, faktor tersebut bepengaruh secara signifikan berdasarkan penelitian terdahulu. Dengan demikian peneliti selanjurnya dapat mengembangkanya.

\section{DAFTAR PUSTAKA}

Naswati, Luluk 2015. Pengaruh Persepsi Siswa Tentang Kewirausahaan, Prestasi Belajar Kewirausahaan dan Praktik Kerja Industri Terhadap Minat Berwirausaha Siswa kelas XII SMK Diponegoro Tumpang Tahun Ajaran 2014/2015. Skripsi Malang: Program Studi Pendidikan Ekonomi Fakultas Ekonimika dan Bisnis Unuversitas Kanjuruhan Malang.

Nitisusastro, Mulyadi. 2010. Perilaku Konsumen Dalam Perspektif Kewirausahaan. Bandung: Alfabeta.

Rusdiana. 2013. Kewirausahaan Teori dan Praktik. Bandung: CV Pustaka Setia. Slameto 2010. Belajar dan Faktor-faktor yang Mempengaruhinya. Jakarta. Rineka Cipta.

Suryana. 2014. Kewirausahaan. Kiat dan Proses Menuju Sukses Edisi 4, Jakarta, Salemba Empat. 